\title{
Re-Singing the World \\ Indigenous Pedagogies and Global Crisis during Conflicted Times
}

\author{
Makere Stewart-Harawira
}

\section{Introduction}

Speaking of the global crisis of sustainability, Noam Chomsky observed, "Throughout the world, Indigenous societies are struggling to protect what they sometimes call 'the rights of nature', while the civilized and sophisticated scoff at this silliness." In particular, Chomsky declared that,

Leading the effort to preserve conditions in which our immediate descendants might have a decent life are the so-called "primitive" societies: First Nations, tribal, Indigenous, aboriginal.... The countries with large and influential Indigenous populations are well in the lead in seeking to preserve the planet. The countries that have driven Indigenous populations to extinction or extreme marginalization are racing toward destruction. ${ }^{1}$

On an earlier occasion, the geographer Bernard Nietschmann made a similar contention.

Where there are nation peoples [place-based communities whose relationships with their homelands (both land and water) govern their roles and responsibilities] with an intact, self-governed homeland, there are still biologically rich environments [...] the converse is equally striking: State environments-where the non-nation peoples live-are almost always areas of destructive deforestation, desertification, massive freshwater depletion and pollution, and large-scale reduction of genetic and biological diversity. ${ }^{2}$

1 N. Chomsky, Will Capitalism Destroy Civilization? TruthOut Op-Ed (7 March 2013), available at $<$ http://truth-out.org/opinion/item/14980-noam-chomsky-will-capitalism-destroy-civilization>, accessed April 2013.

2 Nietschmann 1995, cited in J. Corntassel \& C. Bryce, Practising Sustainable Self-determination: Indigenous Approached to Cultural Restoration and Revitalization, Brown Journal of World Affairs, (Spring-Summer 2012, 18, No. 11), 151 .

(C) MAKERE STEWART-HARAWIRA, 2015 | DOI 10.1163/9789004282087_011

This is an open access chapter distributed under the terms of the prevailing CC-BY-NC License

at the time of publication.

Makere Stewart-Harawira - 9789004282087 
While Chomsky's comment can of course be argued as overly simplistic and reductionist, it nonetheless highlights a critical point of tension for Indigenous peoples in the context of globalization, the tensions between economic development and participation in the global economy, and the preservation of traditional ways of life, including subsistence lifestyles, and of nature itself, with which historically they have held a deep and enduring relationship which defines their identity and their relationships. However, as Cherokee scholar Jeff Corntassel points out "When asked about living sustainably today, Indigenous peoples inevitably confront the ongoing legacies of colonialism that have disrupted their individual and community relationships with the natural world."3

I take these three sets of comments as my starting place for this article in order to contextualize one of the most critical points of tension for Indigenous peoples, that between economic development and participation in the global economy, and preservation of nature, in particular on Indigenous customary lands. As states increase their strategies of reincorporation or dispossession and extinction in response to both the demands of global capitalism and the demands of Indigenous peoples, these tensions are the backdrop for renewed acts of resistance by Indigenous communities across many areas of the globe, At the heart of these issues is the unprecedented expansion of unsustainable resource extraction across every resource-rich territory on the globe, including the traditional territories of Indigenous peoples. This is the backdrop against which Indigenous communities across the globe are enacting a politics of refusal and the place from which Indigenous peoples are engaged in what I have referred to elsewhere as the "re-singing the world."

In writing this chapter, I locate myself as an Indigenous person from Aotearoa New Zealand, a country in which the relationship between the peoples of the land and the settler government is held to be defined by the Treaty of Waitangi, ${ }^{5}$ now living as a guest in the traditional lands of the Cree, Dene,

3 J. Corntassel, "Re-envisioning resurgence: Indigenous pathways to decolonization and sustainable self-determination," in Decolonization: Indigeneity, Education \& Society, Vol. 1, (1), 2012, 87 .

4 M. Stewart Harawira (2012), Returning the sacred: Indigenous ontologies in perilous times. In L. Williams, R. Roberts \& A. McIntosh (Eds.), Radical Human Ecology: Intercultural and Indigenous Approaches (73-88), UK: Ashgate.

5 The Treaty of Waitangi was signed in 1840 between the representative of the British Crown and representatives of certain tribes. Regarded for many years as a 'simple nullity', for several decades Maori have drawn attention to inconsistencies in the official translation, in its representation and the problematic consequences of those inconsistencies. In 1975, the Waitangi Tribunal was established as a permanent commission of inquiry tasked with researching 
Blackfoot, Nakoda, and Anishnabe peoples in the Canadian Province of Alberta, an area covered by three of the eleven numbered treaties signed between the First Peoples of Canada and the British Crown. ${ }^{6}$ The politico/ economic changes currently occurring in both countries, Canada and Aotearoa New Zealand, bear upon the relationship between Indigenous peoples and their rights to their traditional customary practices and way of life in very specific ways. Thus they are integral to my discussion here. One way that these changes can be understood is in relation to the intersection of the crisis of sustainability and the assertion of the rights of capital over state sovereignty, over international human rights law and indeed, over the entire lifeworld. As a global discourse, the crisis of sustainability refers to both an environmental and an economic crisis. In recent years, the concept of "triple crisis" has come to signify the interrelationship between financial, environmental and food security crises that collectively impact the worldwide sustainability of human society. ${ }^{7}$ Indigenous communities intersect the "triple crisis" of sustainability in multiple ways. Located at the intersection of the imperatives for non-renewable energy expansion, sustainability, and ecological preservation, traditional and Indigenous communities occupy about 20 per cent of the world's land surface, often at the margins of arable lands. ${ }^{8}$ The land occupied by Indigenous communities also holds hundreds of gigatons of carbon - the recognition

breaches of the Treaty by the Crown or its agents, and suggesting means of redress. It is recognized today as a founding document of the nation. Nonetheless the meaning and intent of the Treaty of Waitangi continues to be a site of struggle particularly with regard to the concepot of Maori sovereignty. For a useful discussion of this, see David Williams (n.d.), Customary rights and Crown claims: Calder and other Canadian contributions to the revival of the doctrine of aboriginal title in Aotearoa New Zealand, A paper prepared for seminar preparatory to the conference, "Let Right be Done: Calder, Aboriginal Rights and the Treaty Process: Looking Forward, Looking Back," available at <http://pacificguardian.info/files/David\%2oWilliams .pdf>, downloaded May 15, 2014.

6 In Canada, the numbered treaties secured certain areas of traditional lands from the rapid encroachment of settlers and allowed lands outside of these reserved lands to be shared in return for certain promises regarding education, health, the right to hunt, fish and practice their traditional lifestyles for as long as the sun shall rise, the grass grow and the rivers run. Held as sacred by First Nations Chiefs and communities, these promises were broken by the Crown and subsequent governments as quickly as they were made. The Numbered Treaties continue to be sites of struggle over meaning and intent, recognition and redress.

7 Cf. V. Shiva. Soil Not Oil: Environmental Justice in an Age of Climate Crisis. South End Press (2008); Addison, T., Arndt, C., \& Tarp, F. (2010). The Triple Crisis and the Global Aid Architecture. Helsinki: UNU-WIDER.

8 Ovideo, Maffi and Larsen, 2000, cited M. Macchi et. al., Indigenous and Traditional Peoples and Climate Change. IUCN Issues Paper, (Gland: IUCN, March 2008). 
of which has significant implications for industrialized countries seeking to secure significant carbon stocks in an effort to mitigate climate change policies. $^{9}$

In this article I propose that in this contemporary moment, the global and local space within which Indigenous rights to cultural heritage and their traditional relationships with land and territory are mediated and negotiated is directly connected to this "triple crisis of sustainability" through being subsumed within a form of globalization best described as a new form of imperialism. In this context, Indigenous peoples are finding new ways to engage and to reshape their future, and indeed, our collective future. The chapter proceeds as follows. It begins with a clarification of the distinction between ethnic minorities and Indigenous peoples. A theoretical commentary on globalization interwoven with the activities of Indigenous peoples internationally leads to a discussion of the changing role of the nation-state and Indigenous peoplesstates relations. An important theme here is the goal of Indigenous self-determination and its discursive and coercive re-constructions. The final section looks at the recent resurgence of Indigenous activism centred on traditional customary rights and the huge expansion of natural resource extraction occurring in many Indigenous territories. The overarching objective of the article is an endeavor to unpack some of the broader implications of the political struggles of Indigenous peoples in the context of the global crisis of sustainability.

\section{Distinguishing the "Indigenous"}

To begin with, it should be recognized that Indigenous peoples in countries that have experienced internal colonisation, that is to say, countries in which the colonising people settled and stayed, rather than returning to their place of origin ${ }^{10}$ do not conceive of themselves as minorities, or as "ethnic groups." Rather, they regard themselves as sovereign peoples in occupied lands, lands that have been occupied by people whom they originally welcomed as guests, whose subsequent policies and strategies of assimilation and/or extinction saw Indigenous and First Peoples' populations drastically diminished and, at least according to some of the covenants in international law, ${ }^{11}$ become widely reduced to dependent peoples, in many cases with no legal status as

\footnotetext{
$9 \quad$ World Bank, 2008, 23.

10 J. Tully, Public Philosophy in a New Key, Vol. 1. Democracy and Civic Freedom, (Cambridge: Cambridge University Press, 2008a), 258-263.

11 See for instance International Labour Organization Convention 107.
} 
"people."12 Although the term "Indigenous" implies a particular status of "first peoples" to the occupants of a land who were there first, in recent years it has become more widely applied to legitimize claims to special status based on multi-generational occupation, giving rise to a certain ambiguity in the discourse. In contrast, the term first nations or first peoples refers to those who were not only born in the country, but whose ancestors were the first people in the land, or in some cases, according to oral histories, were alwys present in the land. Thus Indigenous peoples claim their lands on the basis of occupation since time immemorial. Some Indigenous groups use the term "tribes" while others prefer to use the nomenclature "Indigenous nations," a political statement by which Indigenous sovereignty is asserted. In her study of Indigenous identity and struggles in the Amazon Basin, Goncalves describes indigeneity as the narrative by which Indigenous peoples explain their political, cultural and social experiences. As Goncalves recounts, it is a narrative about survival and about cooperation and alliances. Described as at once "the historical account of the experience of colonization and the political subjectivity which is embraced through this process,"13 on this and similar accounts, the accounting for and recounting of the historical experience of colonization is as much a definition of indigeneity as is the cosmology of relationality by which indigeneity is also defined.

One of the most important recognized commonalities shared across Indigenous ontologies are genealogies of interconnectedness, that is, the genealogies by which Indigenous peoples trace their ancestral relationships to the land, to the cosmos and to one another. It is not unusual to see Indigenous scholars describe the inseparability between human beings and the natural world as the most important defining characteristic of indigeneity. This is well demonstrated in the following explanation of Maori concepts of whenua (land), by ex-Maori Language Commissioner Patu Hohepa. As Hohepa describes, the physical and spiritual significance of Maori relationship with the land is embedded in the Maori language which connects land and afterbirth, and is given recognition in ceremonies which return the placenta (whenua) to the land (also whenua). Thus Hohepa explains,

12 In Canada, Aotearoa New Zealand and Australia, Indigenous peoples were denied citizenship until the mid-1970s, except under certain circumstances which involved giving up their status as Indigenous peoples. For a comparative account, "see A. Armitage Comparing the Policy of Aboriginal Assimilation: Australia, Canada, and New Zealand, uвC Press, 1995.

13 M. Goncalves, Between the Good Leader of Virtu and the Good Savage. Indigenous Struggles and Life Projects in the Amazon Basin. J. Marshall Bieier (Ed.) Indigenous Diplomacies. N.Y. Palgrave Macmillan (2009), 133-154. 
The words "nooku teenei whenua" (This is my land) is given much stronger meaning because of the above extensions. Having ancestral and birth connections to above is also translated as "I belong to this land, so do my ancestors, and when I die and join them so too will I be totally part of this land."14

It was in similar terms that the late Vine Deloria described the great reluctance of many (North American) tribes to "surrender their homelands to the whites because they knew that their ancestors were still alive on the land."15 Mason Durie has described the relationship with land, forests, waterways, oceans as one of two sets of determining characteristics as key signifiers of what it means to be Indigenous. The first are primary and legally-oriented commonalities to do with human rights arguments, claims to self-determination and sovereignty. The second set of characteristics are to do with systems of knowledge that integrate Indigenous world views, values and experience, the dimension of time and relationship with the environment and deriving from the environment relationship - culture, human identity and group structures and processes that celebrate the ecological union and a language so strongly influenced by the environment that it is not spoken as a first language in any other part of the world. This set of secondary characteristics defines a set of aspirations that sit at the heart of what it means to be Indigenous today. As Durie states elsewhere, "all Indigenous peoples have a tradition of unity with the environment,"16 pointing out that this tradition is reflected in song, customary practice, subsistence life styles, rituals and practices associated with birth, healing, death. Manuka Henare explains that this has historically been translated as meaning that, "the resources of the earth do not belong to humankind; rather, humans belong to the earth,"17 a characteristic that Durie describes as integral to the "shaping of attitudes and thinking," and for "the organizing of Indigenous knowledge."

From these accounts, rather than histories of colonization, dispossession or claims to prior settlement, it is the nature of the relationship with place that is

14 D.V. Williams, The Annexation of New Zealand to New South Wales in 1840: What of the Treaty of Waitangi ? » (1985) 2, Australian Journal of Law and Society 4 (1), cited Williams, D. (n.d.).

15 V. Deloria, God is Red. (Golden, Colarado: Fulcrum Publishing, 1994), 172-173.

16 M. Durie, Nga Tai Matatu. Tides of Maori Endurance. (Victoria; Australia: Oxford Publishing Press, 2005), 137.

17 M. Henare, 2001. "Tapu, Mana, Mauri, Hau, Wairua: A Maori Philosophy of Vitalism and Cosmos," in Indigenous Traditions and Ecology. The Interbeing of Cosmology and Community, ed. John A. Grim. (Cambridge, Ma: Harvard University Press, 2001), 202. 
held to be the most defining characteristic of Indigenous peoples. Here there is no sense of humankind as dominant over creation or that creation exists for humankind to exploit. Rather, humanity is understood as being a part of the entirety of creation in a relationship that carries particular responsibilities of caretaking, of guardianship, of protection. Critical also is the sacred nature of this relationship, a view that is a central tenet of indigenous epistemologies and which is given expression through ceremony, through the chanting and singing of ancient forms of prayer, and through fasting. For many, the concept of 'singing into being', or re-singing the world, is a ritual and practice that inscribes and re-inscribes the profoundly sacred nature of the interrelationship with humankind and the rest of creation.

\section{A Theoretical Lens on Globalization}

The concept of relationality is not, of course, unique to Indigenous peoples but has salience also in discussions about globalization. As a signifier, globalization refers to both a historical process and to the conceptual change in which it is reflected - belatedly and still incomplete, as Arnason noted in 1990, pointing out that interpretations of this process of globalization have proved as prone to reductionism as the theories that were adapted or applied to the nation state. As international economy theorist, R.W. Cox reminds us, theory is not neutral but is always for or on behalf of someone or something. He describes theory as falling into two broad categories - those that maintain the status quo and those that seek to be transformative. ${ }^{18}$ Discussions about globalization inevitably center around certain key thematics - a world order based on the Westphalian state system and interrelationships of governance and democracy, and the relationship between states and the global economy. Accounts of the development of world order commonly adopt approaches which either trace the evolution of modernity from its beginnings in western philosophical political thought or adopt an international relations perspective dominated by the development of the Westphalian model of nation states, the restructuring of Europe under the aegis of the Treaty of Versailles, the postworld war two establishment of the institutions of international order, and the post-1989 emergence of a neoliberal system of government without governance. Other accounts focus on the proliferation of non-state actors such as

18 R. W. Cox, "Social forces, states and world orders: beyond international relations theory," in Approaches to World Order, Robert W. Cox (with Timothy Sinclair). (Cambridge: Cambridge University Press, 1996 [1981]). 
non-governmental organisations (NGOs) and other sectors of civil society. Indigenous, Third World and feminist critiques as well as postmodern analyses of imperialism and neo-imperialism generally fall into the category of alternative accounts. Conceptually speaking, the origins of globalization have been variously located in the exodus from Africa, ${ }^{19}$ thirteenth century Indo-ChinaEurope, reborn again in fifteenth-century European expansionism, ${ }^{20}$ late nineteenth-century European Imperialism, and confined to the late twentieth century. ${ }^{21}$ Some views see the overall processes of globalization as have been occurring for at least two thousand years, ${ }^{22}$ while Marxists Andre Frank and Barry Gills ${ }^{23}$ extend the view of the world system as far back as 5,000 years.

A useful analysis by Gomes, Robertson and Dale describes a critical, relational approach to globalization as one that "relies upon the assumption that the world is and has become even more and more relational." ${ }^{24}$ This, they explain, means that "socio-historical phenomena are interrelated, interdependent, and inter-twined processes, where each one conditions, and is conditioned by, the others; each one constitutes and is constituted by, the others." An important point here is that rather than the real being out there constituted by constituted by a group of facts or given data, "the real is a concrete reconstruction" which can and does take different epistemological and ideological routes. Echoing Cox's comment, Jessop identifies two positions amongst globalization critics that demonstrate these different epistemological and ideological routes - an "ideological category that obscures the continuities between today's global economy and older forms of imperialism, and that of a neutral, scientific concept that can be operationalized, tested, and applied to

19 D. Wilkinson, "Civilizations, cores, world economies, and oikumenes," in The World System: Five Hundred Years or Five Thousand? in Andre Gunder Frank and Barry Gills eds., (Routledge, London; New York, 1996), cited in Stewart-Harawira, The New Imperial Order. Indigenous Responses to Globalisation. (London: Zed Books, 2005).

20 J. Abu-lughod, "Discontinuities and persistence. One world system or a succession of systems?" A.G. Frank and B. Gills, eds. The World System: Five Hundred Years or Five Thousand? (Routledge, London; New York, 1996).

21 J.A. Scholte, Globalization. A Critical Introduction. 2nd ed. (New York: Palgrave MacMillan, 2005 [2000]).

$22 c f$. R. Robertson, Globalization: Social Theory and Global Culture. (London Sage, 1992).

23 A.G. Frank and Barry K. Gills, eds. The world system: five hundred years or five thousand? (London: Routledge, 1996).

24 A.N. Gomes, S.L. Robertson and R. Dale, "The social condition of higher education: globalisation and (beyond) regionalisation in Latin America," in Globalisation, Societies and Education, 10 (2) (2012), 223. 
guide research, strategy and policy."25 These continuities between earlier forms of imperialism and today's global economy are a key focus of Indigenous critiques of globalization in which the acquisition and control of lands and territories that are important either for their mineral wealth or their strategic positioning has been a central goal of key financial/industrial interests. ${ }^{26}$

Importantly, however, and regardless of its ideological and epistemological origins, the shape and contours of globalization that became visible in the second-half of the twentieth century is not a single unitary process but one that is "hyper-complex"27 and as yet incomplete. Taking up an analysis by Panitch and Gindin, ${ }^{28}$ globalization is often usefully conceived of as occurring in stages, the first phase being the 11th to $15^{\text {th }}$ century, the second generally being recognized as beginning in 1989 with American expansionism and given expression in what came to be called the 12 principles of the Washington Consensus that undergirded structural adjustment, firstly in developing countries and then in developed countries. The politically and economically tumultuous 196os and 1970s provides one of the markers of this period of the expansion of global capitalism. They also marked the emergence of a "qualitatively new dimension in contemporary international diplomacy," albeit one with significant historical precedent. ${ }^{29}$ In this period and not for the first time, Indigenous peoples again took their concerns to the international arena.

\section{Indigenous Peoples in the Global Arena}

The struggle of Indigenous peoples to emerge from the paternalism of the colonial past is well documented, particularly with regard to the significant achievements most notably since the 1970 s when Indigenous movements in a sense erupted onto the global stage. Achievements won during this time include the granting of observer status at the United Nation to a number of

25 B. Jessop, "Globalization and the State," in Handbook of Employment and Society: Working Space. (Cheltenham \& Camberley, U K: Edward Elgar Publishing, 2010a), 19.

26 Cf. Z. Brzezinski, The grand chessboard: American primacy and its geostrategic imperatives. (Basic Books, 2007).

27 B. Jessop, "Challenging democratic governance: The impact of globalization on the territorial and temporal sovereignty of the state and the capacities of civil society," in Globality, Democracy, and Civil Society. (London: Routledge, 2011), 19.

28 S. Gindin and L. Panitch, The Making of Global Capitalism: The Political Economy of American Empire (New York: Verso, 2012).

29 J.M. Beiers, "International affairs: Indigeneity, Globality and the Canadian state," in Canadian Foreign Policy Journal, 13 (3), 2007, 121-131. 
Indigenous NGOS, the sometimes successful lobbying of the World Bank regarding projects that involve their dislocation and/or the destruction of sacred sites, lands, and resources, and the revision of International Labour Organization Convention 107- a pernicious document which embedded Indigenous peoples under the guardianship and tutelage of nation states over Indigenous peoples. In this period, the strengthening of international networks of Indigenous peoples saw the emergence of a new "politics of indigeneity" as a critical component in the affirmation of Indigenous peoples' determination to reclaim their histories, epistemologies, cultural rights and political autonomy. In collaboration with non-Indigenous colleagues, advocates, and civil society movements, this global movement of transversal unity (Soguk, 2009) was in large measure responsible for significant changes in their relationships with the international system of nation states as well as the international juridical human rights system. A series of meetings that formalized the presence of Indigenous peoples' missions in the United Nations with the establishment of the UN Working Group on Indigenous People marked the beginning of twenty-five years of protracted struggle for the recognition of Indigenous rights, leading finally, to first the passing of the Draft Declaration on the Rights of Indigenous Peoples to the UN General Assembly, and in November 2007, the ratification and passage of the UN Declaration on the Rights of Indigenous People (UNDRIP) into International human rights law. Significantly, of the 159 states represented at the General Assembly at the time of the vote, the only four states to vote against the adoption of the Declaration, i.e. Australia, Canada, the United States, and New Zealand, are former British colonies, each with sizable Indigenous peoples living within their nation-state borders.

These states cited fundamental incompatibilities between the Declaration and their respective constitutional and legal frameworks, eventually endorsing the Declaration to the extent that each reconciled what had been perceived to be inherent incompatibilities with their existing laws. The predominating logic behind their later reconciliation was that the spirit of the UN Declaration on the Rights of Indigenous Peoples was acceptable only because implementation of contentious articles was non-binding. One such article of critical significance to Indigenous peoples is Article 3 which declares that, "Indigenous peoples have the right to self-determination. By virtue of that right they freely determine their political status and freely pursue their economic, social and economic development." ${ }^{30}$ Equally critical is the protection of rights to

30 United Nations, 2007, Declaration on the Rights of Indigenous Peoples, United Nations: <http://www.un.org/esa/socdev/unpfii/documents/DRIPS_en.pdf>. 
cultural expression, practice of traditions, relationships with their land and territories embedded in Articles 11-3 and 24-27. Speaking of the Declaration's import, New Zealand Prime Minister John Key declared that his government "did not sign up to anything; [it] affirmed a declaration that is non-binding and aspirational." ${ }^{31}$ For the United Kingdom's ambassador to the United Nations, Karen Price, feeling the need to re-emphasize the non-binding nature of UN declarations, the UN Declaration on the Rights of Indigenous Peoples had to remain effectively symbolic, since it was "non-legally binding and did not propose to have any retroactive application on historical episodes." ${ }^{32}$ The government of Canada went further, declaring the Declaration to be "non-legally binding document that does not represent customary international law nor change Canadian laws" (Anaya, 2010). The Declaration itself points to limitations in its proposal. Article 4, for instance, limits the "Indigenous right to autonomy or self-government in matters relating to [only] their internal and local affairs," echoing the contention over potential secession that states had consistently argued lay at the base of their consistent and continuing objection to any notion of Indigenous peoples self-determination. Responding to the passing of the Declaration, Ward Churchill $(2011,526)$ argued that its "delineation of Indigenous rights not only fails to fulfill the aspirations of those who pursued such an articulation during the last quarter of the twentieth century, but reflects a radical disjuncture from previous codifications of the right to self-determination in international law." By co-opting the term "selfdetermination," stated Churchill, the Declaration's rhetoric underscores a 'consecration' of legal-frameworks that continue to marginalize and disenfranchise Indigenous peoples. In this sense, then, the UN Declaration on the Rights of Indigenous Peoples is another manifestation of the ongoing tension between state-sovereignty and Indigenous self-determination. ${ }^{33}$

While the Un Declaration on the Rights of Indigenous Peoples, notwithstanding its many inherent oversights, was a landmark for the recognition of Indigenous-rights in international law, Indigenous interventions that in various forms have been integral to Indigenous strategies of resistance and reconciliation since the earliest days of colonisation remain persistent in the global

31 UN Declaration on the Rights of Indigenous Peoples-Government Support: <http:// www.parliament.nz/en-NZ/PB/Business/QOA/8/3/d/49HansQ_20100420_00000001-1-UN -Declaration-on-the-Rights-of-Indigenous.htm $>$.

32 United Nations 2007. General Assembly Adopts Declaration on Rights of Indigenous Peoples: <http://www.un.org/News/Press/docs/2007/ga10612.doc.htm>.

33 As Indigenous scholars such as Franke Wilmer and Taiaiaeke Alfred have remarked, the term sovereignty is itself is a product of a colonial imaginary. For a more extensive discussion of sovereignty, see Stewart-Harawira, 2005, 114-144. 
political arena. Indeed it is at the intersection of Indigenous demands for the recognition of Indigenous rights and environmental crisis that these counter discourses have emerged as one of the most powerful voices against the devastating impacts of global capitalism. Since the 1990s, and earlier, denied equal representation with states at high-level international conferences seeking to address urgent issues of biodiversity, Indigenous peoples have sought other venues, often in parallel meetings to the regional and international conferences from which they were excluded, and in which they were denied representation, in which they have repeatedly referred to the warnings of their ancestors and voiced their concerns for the environment and for the denial of their rights to protect their own territories from destructive development processes. From the first World Indigenous People's Conference on Territories, Rights and Sustainable Development, Kari-Oca I which resulted in the "KariOca Declaration" to other declarations such as the "Declaration of Quito, Ecuador. Indigenous Alliance of the Americas on 500 Years of Resistance," the "Cochabamba Declaration (2010) which called for the establishment of an International Climate Justice Tribunal," and more recently, Kari-Oca II (2012), Indigenous peoples have reaffirmed their rights to retain their languages, engage in their cultural practices including subsistence lifestyles, and the urgency of the need to protect nature. They have called attention to the impact of destructive practices in agriculture, mining and water management and to the need for a new global paradigm that restore the harmony between nature and human beings. In all cases, the relationship is described in terms which emphasis its fundamental nature of interdependent, indivisible, and spiritual.

A significant number of very important and successful outcomes of Indigenous peoples' international efforts for recognition of the importance of traditional ecological knowledge and of Indigenous practices of sustainability have ensued that are directly attributable to these endeavors. They include recognition in the Convention on Biological Diversity (СвD) which resulted from the 1992 UNEP "Earth Summit" conference at Rio de Janeiro, the International Indigenous Forum on Biodiversity (IIFB) formed at the III Conference of the Parties to the Convention on Biological Diversity (COP III) in Buenos Aires, Argentina, in November 1996, the 2008 World Bank report The Role of Indigenous Peoples in Biodiversity Conservation and many other regional and international instruments and reports. Important as they are, however, as with the UNDRIP and other international human rights instruments, due to the nature of the international structure of governance, these mechanisms fail to protect Indigenous peoples' rights to protect their traditional lands and practice their customary lifestyles. Indeed, as Tully argues, "rather than freeing [Indigenous peoples] from long-standing internal colonisation, the struggle for recognition 
has tended to reproduce it in an altered and ameliorated form without effectively challenging, negotiating and modifying the forms of deeply sediments colonial conduct of both non-Indigenous and indigenous peoples that sustain it." ${ }^{34}$

Yet despite the inherent limitations of the UNDRIP, its ratification and eventually, endorsement by the cANzus group of states (of which Canada was the last to sign), was widely seen as having a significant impact on Indigenous peoples-states' relationships. From some perspectives, it marked the culmination of the shift from assimilation by states to the recognition of the right to self-determination, a right that in some cases was advanced through renegotiated treaty settlements ( $c f$. Aotearoa New Zealand and British Colombia, Canada) was under-scored by much-heralded apologies from governments (Canada, New Zealand, Australia), by long-fought for recognitions of the right to be consulted about industrial development on their traditional territories and the development of co-management regimes and benefit-sharing agreements, and by reconciliation strategies which attempt effect redress for the appalling treatment of Indigenous children in residential schools during the twentieth century. From other perspectives, the shift in state policies from assimilation to accommodation of rights in a politics of recognition that Corntasse ${ }^{35}$ describes as the "illusion of inclusion" results in a reconfiguring of the same forms of colonial power that Indigenous peoples' demands for recognition sought to transcend. ${ }^{36}$ The recognition of Indigenous rights, won through long protracted struggles and often at great personal and community cost, is at all times mediated by states' proscribing of conditionalities that limit the extent to which these outcomes achieve their aims and objectives. While Indigenous peoples' demands for recognition of customary rights and practices constantly challenge the legitimacy of settler states, states are continuously seeking new ways to limit or redefine these rights and reincorporate Indigenous natural resources into their own economic agenda. Tully ${ }^{37}$

34 J. Tully, Public Philosophy in a New Key, Vol. 2. Imperialism and Civic Freedom. (Cambridge: Cambridge University Press, 2008b), 67.

35 J. Corntassel, "Partnership in Action? Indigenous Political Mobilization and Co-optation During the First UN Indigenous Decade (1995-2004)," in Human Rights Quarterly, 29, (2007).

36 G.S. Coulthard, "Subjects of Empire: Indigenous Peoples and the 'Politics of Recognition' in Canada," in Contemporary Political Theory, 3 (2007), cited in J. Corntassel \& C. Bryce, Practising Sustainable Self-determination: Indigenous Approached to Cultural Restoration and Revitalization, Brown Journal of World Affairs, (Spring-Summer 2012, 18, No. 11), 152 . 
describes this in terms of "participation in relations of governance of production, consumption, militarism, securitization, leisure and so on." In this fashion, the recognition of Indigenous peoples' rights has been accompanied by further retrenchment and resistance on the part of some states and renewed efforts to re-incorporate Indigenous peoples into the capitalist state. A process well entrenched since the early days of colonialism, this has typically involved reshaping and corporatization of traditional Indigenous governance structures, the interpretation of 'capacity-building' as capitalist modes of economic development and the incorporation of local Indigenous communities within capitalist structures which took for granted ideologies based upon notions of homo economicus and the diminishment of traditional Indigenous values of collectivity and relationality.

\section{Imperial Relations in a Post-Colonial World}

The backdrop to this politics is the restructuring of the nation state by neoliberal forms of imperialism, ${ }^{38}$ a shift to a universal "debt regime," the emergence of new economic structures of global governance and the redefinition of notions of development and state sovereignty. In the 1980s and 1990s, the development of regime theories and the popular liberal notion of "governance without government" raised critical questions about a reconfiguring of the principles and practices of democracy. During this period the concept of "rolling back of the state" gained considerable purchase in some quarters, as did notions of "limited democracy." ${ }^{39}$ Some theorists argue for a state that is considerably weakened, or rolled back, leaving the floor open for alternative structures of governance, while others argue that while globalization has seen changes in the role of the state, the state has always acted as an agent of capital and that far from being diminished, the role of the state as an agent in the establishment of global capitalism has been integral. Here the notion of the "hollowing out of the state" has been a useful explanatory tool. ${ }^{40}$ Jessop (and others) has been careful to point out that, "Just as globalization does not

38 P. McMichael, "The new colonialism: global regulation and the restructuring of the interstate system," in New World Order? Global Transformations in the Late Twentieth Century. Eds. D. A. Smith, and J. Borocz (Westport, Conn.: Greenwood Press, 1995), 37-53.

39 Cox, 1954, 54.

40 B. Jessop, "Capitalism and Its Future: Remarks on Regulation, Government and Governance," in 4: 3, Review of International Political Economy, The Direction of Contemporary Capitalism (Autumn, 1997), 561-581. 
generate a single set of pressures that affect all states equally, there is no common response by all states to the multiple forms assumed by globalization." ${ }^{41}$ Under neoliberalism, Jessop states, the relationship between the state and the market is fraught with contradictions. Nonetheless, in 2008, the "continued reciprocal interdependence of 'market' and 'state' as complementary moments of the capital relation" 42 was brought sharply into focus as the financial crisis of neoliberalism brought the essential nature of the states-market relationship to the fore.

In 1898, informal imperialism was a means of asserting us rights to free markets "in all the old countries which are being opened up to the surplus resources of the capitalistic countries and thereby given the benefits of modern civilization." 43 The popular assumption that the decolonization program begun in the 1960 also represented the end of imperialism has been slow in its decline. As Tully remarks, global democracy authors have promoted the notion that the global transformations of the 1990s and the shift to global governance represented a welcome move towards global democracy. ${ }^{44}$ The reality, however, is that not only is the international human rights system troublingly flawed, it fails at the most fundamental level to protect the rights of Indigenous peoples living within internally colonized territories. The cause of this failure lies in the dominance of capital over human rights. This most notably includes the exercise of cultural rights and norms and the rights to protect traditional lands from destructive forms of exploitation. As Jessop points out, states are heavily implicated as agents in this process. Internal and external forms of colonization having succeeded in gaining access to the natural resource wealth of Indigenous peoples, today the recognition of Indigenous customary rights represents a potential barrier to the full realization of the interests of capital. The response from states in alignment with capital has been instructive. Faced with the refusal of Maori to accept the extinguishment of their rights through the ongoing treaty claims process, the New Zealand government's response was to overturn the previous jurisdiction of the Maori Land Court to hear and determine Maori customary claims relating to the foreshore and seabed, thus effectively extinguishing Maori claims to the foreshore and seabed, ${ }^{45}$ and in 2006, to vociferously oppose the passing of the UN Draft Declaration within

\footnotetext{
41 Jessop 2010b, 42.

42 Jessop 2010b, 39.

43 Conant, 1898 , cited Tully $2008 \mathrm{~b}, 132$.

44 Cf. D. Held, Global Covenant: The Social Democratic Alternative to the Washington Consensus, (Polity Press, 2004).

45 New Zealand Foreshore and Seabed Act 2004.
} 
the UN Human Rights Council. By 2012 and in the second term of the National government administration led by Prime Minister John Key, legislative action had escalated to include the passage of legislation aimed at undercutting existing environmental protection embedded in the NZ Resource Management Act, ${ }^{46}$ freeing up restrictions on certain kinds of development on customary Maori lands, and placing major state-owned hydro power stations on the open market in a move that presaged wide-scale marketing of the country to foreign investment, opened up vast swathes of the country to gold and oil mining, including deep sea oil mining, and granted approval for an open-cast coal mine on Denniston Plateau on ecologically unique conservation land. The response by Maori community people in the region where deep sea oil exploration was commencing was to take to the ocean - by a range of methods, including swimming - to protest the intrusion of oil drilling in their customary fishing areas. Similar protests have been held around much of the New Zealand coastline. In a country well known for the exercise of the democratic right to protest, the reaction by government was to pass under urgency legislation by means of which protests on the open ocean within certain conditions are deemed illegal and incur extraordinarily punitive outcomes. ${ }^{47}$

Parallel processes occurred in Canada. There, the enactment of the two huge omnibus bills passed rapidly into law by the Canadian federal government and the well advanced plans to build an extensive pipeline network carrying oil south into the United States (the Keystone pipeline), west to the coast of British Colombia for export to China (the Northern Gateway pipeline), and east to the opposite coast, prompted a fresh resurgence of Indigenous activism and protest which has galvanised communities across the continent of North America. In March 2012, following the announcement of the first Omnibus Bill, Bill C-38, ${ }^{48}$ a Bill which decimated existing environmental protections of waterways, including impact assessments of over water pipelines and rights of consultation, in temperatures of minus 25 degrees centigrade and below, a group of youth from a remote Northern Aboriginal community began a 45 day 4,00o km trek on foot, dragging their necessities by sled. Their objective was to meet with the Canadian Prime Minister to demand federal protection of the

\footnotetext{
$46 \quad$ New Zealand Resource Management Reform Bill 2012 No. 93-91.

47 Cf. the NZ Crown Minerals Amendment Act 2013, otherwise known as the "Anadarko Amendment" in recognition of the fact that its passage enabled the Anadarko oilrig to begin operations in New Zealand waters in the face of fierce public opposition.

48 Jobs, Growth and Long-Term Prosperity Act S.C.2012, c.19, Bill C-38 and its companion, Bill $C-45$, also known as the 'Jobs and Growth Act' are further discussed in Duplassie, R, p. 131, footnotes 422 to 425 , this volume.
} 
waterways. Prime Minister Harper's refusal to meet with them when they arrived in Ottawa exhausted and ill but having gathered many supporters along the way, fuelled already high tensions and concerns. In November 2012, as Duplassie describes (pp. 130 this volume), months of gathering outrage catalyzed a nation-wide uprising under the nomenclature of "Idle No More," a movement which immediately connected to the global wave of opposition against the expansion of oil extraction activities across Indigenous lands. As in all Indigenous counter-movements, for Idle No More participants, traditional practices of ritual and ceremony are integral in the reconnection and strengthening of body, mind and spirit to the land and to the ancestors. In this sense, ceremony provides the framework and the means to hold the space for reclamation of rights, reclamation of land, and the reclamation of spirit. Today, across the globe the Indigenous resurgence movement is reuniting Indigenous communities as well as hearts and minds using the tools of non-violent protest against the destruction of their lands - ceremony, dance, prayer, singing, and the politics of refusal.

\section{Negotiating the Spaces}

Nothing in the previous section should be read as implying that Indigenous communities have no involvement in natural resource extraction. The right to determine for themselves their modes of development is a central plank in Indigenous demands for recognition of the right to self-determination, particularly forms of economic development that will move Indgenous communities out of poverty. ${ }^{49}$ Thus Indigenous involvement in benefit-sharing partnerships involving natural resource extraction on their lands has been an important pragmatic response to the encroachment of resource extraction on Indigenous lands. In such cases Indigenous leaders legitimately argue that, given that the development will occur with or without them, it makes good economic sense to participate, and to bring whatever benefits possible to their communities. ${ }^{50}$ Here Bolivia provides a useful insight. Latin America, the site of the

49 The slogan 'out of poverty' dominated the International Indigenous Conference on Mining which I attended in Ontario in 2010. This was concretized in two concurrent sessions, one an Indigenous caucus, the other, Mining 101. Attendance at the former session was no more than a dozen people while the latter was attended by well over 200

$50 \quad$ R.B. Anderson, L.P. Dana, and T.E. Dana. "Indigenous land rights, entrepreneurship, and economic development in Canada: 'Opting-in' to the global economy," 41: 1 in Journal of World Business (2006), 45-55. 
most radical opposition to neoliberal restructuring in the past five years, emerged as one of the strongest examples and symbols of hope for the Indigenous sovereignty movement, as Chomsky acknowledges. By the 1980s, the internationalization of the Guatemalan Mayan struggle and other Latin American Indigenous movements saw Indigenous Latin America become highly visible in the global community. In the 1990s, the Indian movements of Ecuador, Quechua, Mexico's Zapatistas, and the Aymara and Quechan peoples of Bolivia, and the awarding of the Nobel Peace Prize to one of Latin America's foremost Indigenous women, Rigoberta Manchu, signaled new levels of Indigenous engagement and visibility in Latin America which impacted on Indigenous movements throughout the world.

During the same period, the increasing influence of new forms of liberalism had a proscribing influence that shaped these relationships in problematic ways. In January 2006 in Bolivia, the presidential inauguration of the Indigenous leader of a nationally unified movement which was reclaiming control over Bolivia's natural resources signaled a new moment in the relationship between the nation state of Bolivia and Indigenous peoples, giving effect to the right of Indigenous peoples to control their own natural resources and to open new possibilities for deepened, more inclusive forms of democracy. Two of Morales' key policy planks are economic prosperity and the re-nationalization of resources. The re-nationalization of oil development and its removal from the control of foreign interests is integral to these aims. In both Canada and Aotearoa New Zealand, a number of Indigenous leaders advocate for participation in oil development, provided it is done "sustainably." In truth, as the excesses of laissez-faire capitalism deposit their legacy of toxification into the lands and water on which many Indigenous communities depend, the choice not to engage likewise becomes impossible to sustain. As Corntassel asks, "what happens when the medicines, waters, and traditional foods that Indigenous peoples have relied on for millennia to sustain their communities become contaminated with toxins? What recourse do we have against those destructive forces and entities that have disconnected us from our longstanding relationships to our homelands, cultures and communities?"51 For many, the choice between extremes of poverty and economic development that is gained through participation in the benefits of resource extraction in a time of unprecedented ecological and economic crisis becomes an almost unbearable tension.

$5^{1}$ J. Corntassel, Re-envisioning resurgence: Indigenous pathways to decolonization and sustainable self-determination, Decolonization: Indigeneity, Education \& Society, Vol. 1, (1), (2012), 88 . 
In a period when the demand for the worlds' remaining resources combined with new technologies to extract previously inaccessible resources in the remotest regions, are putting even the most isolated minorities and Indigenous peoples under increasing threat from governments and private companies wanting to profit from the resources found on or under their lands, the supremacy of market-based capitalism coupled with what can only be described as a frenetic and frantic last grab at the diminishing (and, due to melting ice and permafrost, newly-accessible) minerals propels renewed policies of exclusion and disenfranchisement. From the point of view of investors, Indigenous communities' opposition to destructive policies of excessive natural resource exploitation represent one of the greatest stumbling blocks to 'realizing' these assets. For states, there are two possible responses, either reincorporation of Indigenous communities into market capitalism or new forms of dispossession and extinction through legislation. Reconciliation strategies that result in the extinction of Indigenous claims to rights achieve both, as do benefit-sharing agreements which exchange rights to customary practices of sustainability for income-generation. For Indigenous communities similarly, there are two broad sets of responses, accommodation with a view towards greater economic self-determination, or resistance. Between each end of the scale, of course, lies a more nuanced range of responses, including "transformation from within" in the classic master's house and tools approach. Tully accurately identifies critical problems with this approach. When these tactical approaches are viewed alongside the corresponding way in which imperial power is informally exercised, these forms of resistance model the ways in which subalterns are conscripted to "unwillingly play a role in developing these imperial relationships." ${ }^{52}$

As the realities of increasingly fragile ecosystems, the severity of droughts, increasingly high temperatures and devastating storms demonstrate, the time for nuanced responses and endeavors to transform 'from the inside' may have run out. For if there is a single signifier of the abject failure of globalization in the twenty-first century, it is surely the damage that has been wreaked upon the earth's biodiversity, and the consequential fragility of sustainable life on this planet. Against the backdrop of the commodification of the biosphere and the ongoing excesses of global capitalism's reach into local economies, the failure of neoliberal globalization to bring promised benefits to Indigenous peoples or indeed, to the overwhelmingly largest percentage of humanity is best demonstrated by the enormity of the triple crisis of sustainability. The extreme by recent reports such as the 2012 World Bank report entitled Turn Down the 
Heat: Why a $4^{\circ} \mathrm{C}$ Warmer World Must be Avoided which notes that countries' current emission pledges and commitments are alarmingly inadequate and "would most likely result in 3.5 to $4^{\circ} \mathrm{C}$ warming, emphasizing that this would be marked by extreme heat-waves, declining global food stocks, loss of ecosystems and biodiversity, and life- threatening sea level rise." In May 2013, new research from Europe showed that a $4^{\circ} \mathrm{C}$ global temperature rise is well within the range of possibility this century, the cost of which will mean "human disaster" for the planet and includes the effect of the world's oceans reaching their capacity to absorb much of the world's carbon pollution creating "catastrophe across large swaths of the Earth, causing droughts, storms, floods and heatwaves, and drastic effects on agricultural productivity leading to secondary effects such as mass migration." In November 2013, a group of scientists led by Jim Hansen declared that the agreed limit of 2 degrees $C$ of global warming places the survival of humanity at extreme risk. ${ }^{53}$ In November 2013 the $5^{\text {th }}$ IPCC report spelled out in unequivocal terms the risk to human life that the world faces in this temporal moment, one which is increasingly called 'the sixth great extinction'. In 2014, reports that seek to highlight for the public the dangers to survival with which the world is now faced include the March 2014 report by NASA climatologist, Drew Shindell, which warned that global warming may increase by 20 per cent. ${ }^{54}$ In contrast to the Intergovernmental Panel on Climate Change's (IPCC) estimate of 1.8 degrees, Shindell's study estimates a transient climate response of 3.06 degrees. More recently, the American Association for the Advancement of Science Climate Sceince Panel took the unprecedented step of developing a range of initiatives to warn the American public that climate change puts the well-being of people of all nations at risk. ${ }^{55}$

For many Indigenous people, the active engagement in the re-singing of the world in this time is not only a reclaiming of Indigenous ontologies, Indigenous ways of being and knowing and living in the world, it is perhaps humanities greatest hope for survival. The resurgence of Indigenous movements is predicated on a return - not to a life without the basic benefits of modernization - though our unchecked collective actions may yet bring that

53 J. Hansen, P. Kharecha, M. Sato, et.al. "Assessing 'dangerous climate change': required reduction of carbon emissions to protect young people, future generations and nature," in Plos One 8 (12), 2013.

54 D. Shindell, "Inhomogeneous forcing and transient climate sensitivity," in Nature Climate Change 4, 274-277, 2014.

55 M. Molina, J. McCarthy, D. Wall, R. Alley, et. al., What We Know. The Reality, Risks and Response to Climate Change, available at <http://whatweknow.aaas.org/wp-content/ uploads/2014/o3/AAAS-What-We-Know.pdf>, downloaded May 16, 2014. 
upon all of us - but to a restoration of the relationship between human beings and the lifeworld, to a profound recognition of our deep interconnectedness across all species and a return to the recognition of the sacred in all things. The re-singing of Indigenous ontologies into the re-singing of the world directly engages the urgent need for a new global paradigm for our shared future. This is without doubt our greatest and most urgent challenge.

\section{Bibliography}

Abu-lughod, J. "Discontinuities and persistence. One world system or a succession of systems?" A.G. Frank and Barry Gills, eds. The World System: Five Hundred Years or Five Thousand? Routledge, London; New York, 1993: 278-291.

Addison, T., C. Arndt and F. Tarp. "The Triple Crisis and the Global Aid Architecture." Working Paper No. 2010/01. New Directions in Development Economics program. (United Nations University (UNU) and World Institute for Development Economics Research (WIDER), Helsinki, 2010).

Anaya, S.J. "The Right of Indigenous Peoples to Self-Determination in the Post Declaration Era." Indian and Northern Affairs Canada, "Canada's Statement of Support." November 12, 2010.

Anderson, R.B., L.P. Dana and T.E. Dana. "Indigenous land rights, entrepreneurship, and economic development in Canada: 'Opting-in' to the global economy," 41: 1 Journal of World Business, 2006: 45-55.

Arnason, J.P. "Nationalism, globalization and modernity." Theory, Culture \& Society June 1990, 7 (2) 207-236. doi: 10.1177/026327690007002013.

Beiers, J. Marshall. "International affairs: Indigeneity, Globality and the Canadian state." Canadian Foreign Policy Journal, 13 (3), 2007: 121-131.

Brzezinski, Z. The grand chessboard:American primacy and its geostrategic imperatives. Basic Books, 2007.

Chomsky, N. "Will Capitalism Destroy Civilization?" TruthOut Op-Ed (7 March 2013), available at <http://truth-out.org/opinion/item/14980-noam-chomsky-will-capital ism-destroy-civilization>, accessed April 2013.

Churchill, W. "Travesty A Travesty of a Mockery of a Sham: Colonialism as 'SelfDetermination' in the Un Declaration on the Rights of Indigenous Peoples." Griffith Law Review, 2011, 20 (3): 526-556.

Conant, C.E. "The Economic Basis of Imperialism." North American Review 167 (502), $1898,326-341$.

Corntassel,J. "Partnership in Action? Indigenous Political Mobilization and Co-optation During the First UN Indigenous Decade (1995-2004)." Human Rights Quarterly, 29, 2007, available at $<\mathrm{http}$ ://www.corntassel.net/partnershipinaction_new.pdf $>$. 
Corntassel, J. "Re-envisioning resurgence: Indigenous pathways to decolonization and sustainable self-determination." Decolonization: Indigeneity, Education \& Society, Vol. 1, (1), 2012: 86-101.

Corntassel, J and C. Bryce. "Practising Sustainable Self-determination: Indigenous Approached to Cultural Restoration and Revitalization." Brown Journal of World Affairs, Spring-Summer 2012, 18, (11): 151-162.

Coulthard, G.S. “Subjects of Empire: Indigenous Peoples and the 'Politics of Recognition' in Canada." Contemporary Political Theory, 3, 2007: 1-29.

Cox, R.W. "Social forces, states and world orders: beyond international relations theory." Approaches to World Order, Robert W. Cox (with Timothy Sinclair), Cambridge: Cambridge University Press, 1996 [1981].

Deloria, V. God is Red. Golden, Colarado: Fulcrum Publishing, 1994.

Durie, M. “Indigenous Knowledge Within a Global System." Higher Education Policy, 18, 2005: 301-312.

Durie, M. Nga Tai Matatu. Tides of Maori Endurance. Victoria; Australia: Oxford Publishing Press, 2005.

Frank, A.G. and B.K. Gills, eds. The world system: five hundred years or five thousand? London: Routledge, 1996.

Gills, B.K. and W.R. Thompson, eds. Globalization and global history. London: Routledge, 2006.

Gindin, S. and L. Panitch. The Making of Global Capitalism: The Political Economy of American Empire. New York: Verso, 2012.

Gomes, A.N., Robertson, S.L., and Dale, R. "The social condition of higher education: globalisation and (beyond) regionalisation in Latin America". Globalisation, Societies and Education, 10 (2), 2012: 221-245. doi: 10.1080/14767724.2012.677708.

Goncalves, M. Between the Good Leader of Virtu and the Good Savage. Indigenous Struggles and Life Projects in the Amazon Basin. J. Marshall Bieier (Ed.) Indigenous Diplomacies. N.Y. Palgrave Macmillan, 2009: 133-154.

Gordon, L.J., G.D. Peterson and E. Bennet. "Agricultural modifications of hydrological flows create ecological surprises." 23 Trends in Ecology and Evolution, 2008: 211-219.

Government of Canada, Jobs, Growth and Long-term Prosperity Act S.C. 2012, c. 19, available at <http://laws-lois.justice.gc.ca/PDF/J-o.8.pdf >.

Hansen, J., P. Kharecha, M. Sato, et. al. “Assessing 'dangerous climate change': required reduction of carbon emissions to protect young people, future generations and nature." Plos One 8 (12), 2013.

Harvey, D. The New Imperialism. Oxford: Oxford University Press, 2003.

Held, D. Global Covenant: The Social Democratic Alternative to the Washington Consensus, Polity Press, 2004.

Held, D. and A.G. McGrew, D. Goldblatt and J. Perraton, Transformations Global. Politics, Economics, and Culture, Stanford, Ca; Stanford University Press, 1999. 
Henare, M. 'Tapu, Mana, Mauri, Hau, Wairua: A Maori Philosophy of Vitalism and Cosmos', in Indigenous Traditions and Ecology. The Interbeing of Cosmology and Community. John A. Grim, ed. Cambridge, Ma: Harvard University Press, 2001: 197-221.

Hirst, P. and G. Thompson. Globalisation in Question: The International Economy and the Possibilities of Governance. Susan McGrath-Champ et. al., ed. Cambridge: Polity, 1996.

Jessop, B. "Towards a Schumpterian workfare state? Preliminary remarks on postFordist political economy." 40 Studies in Political Economy, 1993: 7-39.

Jessop, B. "Capitalism and Its Future: Remarks on Regulation, Government and Governance," in 4: 3. Review of International Political Economy, The Direction of Contemporary Capitalism. Autumn, 1997: 561-581.

Jessop, B. "Globalization and the State," in Handbook of Employment and Society: Working Space. Cheltenham, U K: Edward Elgar, 2010a: 19-34.

Jessop, B. "The 'return' of the national state in the current crisis of the world market." 34: 1 Capital and Class. February 2010b: $38-43$.

Jessop, B. "Challenging democratic governance: The impact of globalization on the territorial and temporal sovereignty of the state and the capacities of civil society." Globality, Democracy, and Civil Society. London: Routledge, 2011: 5-94.

Macchi, M. et. al. "Indigenous and Traditional Peoples and Climate Change". IUCN Issues Paper. Gland: IUCN, March 2008.

Mario Molina, J., McCarthy, D., Wall, R., Alley, et. al. "What We Know. The Reality, Risks and Response to Climate Change," The AAAS Climate Science Panel Report, 2014, available <http://whatweknow.aaas.org/wp-content/uploads/2014/o3/AAAS-What -We-Know.pdf>.

McMichael, P. "The new colonialism: global regulation and the restructuring of the interstate system." New World Order? Global Transformations in the Late Twentieth Century. David A. Smith and Joszef Borocz, eds. Westport, Conn.: Greenwood Press, 1995: 37-53.

McCreary, T. and R.A. Milligan, "Pipelines, permits, and protests: Carrier Sekani encounters with the Enbridge Northern Gateway Project." 2: 1 Cultural Geographies, 2014: 115-129.

Nietschmann, B. "The Fourth World: Nations Versus States." Reordering the World: Geopolitical Perspectives on the 21st Century. George J. Demko and William B. Wood, eds. Philadelphia: Westview Press, 1995: 239.

Oveido, G., Maffi, L., Larson, P.B. “Indigenous and Traditional Peoples of the World and Ecoregional Conservation. An intergrated approach to preserving the world's cultural and biological diversity." Gland: WWF, 2000.

Potsdam Institute for Climate Impact Research and Climate Analytics, "Turn Down the Heat. Why a 4 degrees C Warmer World Must be Avoided," (Washington: World Bank, November 2012), available at <http://climatechange.worldbank.org/sites/ 
default/files/Turn_Down_the_heat_Why_a_4_degree_centrigrade_warmer_world _must_be_avoided.pdf >.

Ridgeway, S. and P. Jacques. The Power of the Talking Stick: Indigenous Politics and the World Ecological Crisis. Boulder, Us: Paradigm Publishers, 2013.

Robertson, R. Globalization: Social Theory and Global Culture. London Sage, 1992.

Robertson, R. "Social theory, cultural relativity and the problem of globality." Anthony D. King (ed.) Culture, Globalization and the World System: Contemporary Conditions for the Representation of Identity. University of Minnesota Press, Minnesota, 2011 [1991, 1997]: 69-90.

Robertson, R. The three waves of globalization: a history of a developing global consciousness. Zed, 2003.

Russi, D., P. ten Brink, A. Farmer, T. Badura, D. Coates, J. Förster, R. Kumar and N. Davidson, The Economics of Ecosystems and Biodiversity (TEEB) for Water and Wetlands, 2013. At <http://www.teebweb.org/wp-content/uploads/2013/o4/TEEB _WaterWetlands_Report_2013.pdf >.

Schellnhuber, H.J., K. Frieler and P. Kabat. "The Elephant, the Blind, and the intersectoral intercomparison of climate impacts." Proceedings of the National Academy of Sciences, 2013 (early online edition). [doi:10.1073/pnas.1321791111], to be available @ $<$ www.pnas.org/cgi/doi/10.1073/pnas.1321791111>.

Scholte, J.A. Globalization. A Critical Introduction. 2nd ed. New York: Palgrave MacMillan, 2005 [2000].

Shindell, D. Nature Climate Change 4, 274-277, 2014. doi:10.1038/nclimate2136.

Shiva, Vandana. Soil Not Oil: Environmental Justice in an Age of Climate Crisis. South End Press, 2008.

Soguk, N. "Communicatio/Excommunication. Transversal Indigenous Diplomacies in Global Politics." Indigenous Diplomacies, M. Beiers, ed. New York: Palgrave MacMillan, 2009.

Stewart-Harawira, M. The New Imperial Order. Indigenous Responses to Globalisation. London: Zed Books, 2005.

Stewart-Harawira, M. "Responding to a Deeply Bifurcated World: Indigenous Diplomacies in the 21st Century." Indigenous Diplomacies. M. Beiers, ed. New York: Palgrave MacMillan, 2010: 207-224.

Stewart-Harawira, M. "Returning the sacred: Indigenous ontologies in perilous times." Radical Human Ecology: Intercultural and Indigenous Approaches. L. Williams, R. Roberts and A. McIntosh, eds. UK: Ashgate, 2012.

Tully, J. Public Philosophy in a New Key, Vol. ı. Democracy and Civic Freedom. Cambridge: Cambridge University Press, 2008 (a).

Tully, J. Public Philosophy in a New Key, Vol. 2. Imperialism and Civic Freedom. Cambridge: Cambridge University Press, 2008 (b).

Turner, D. This is Not a Peace Pipe. Towards a Critical Indigenous Philosophy. Toronto: University of Toronto Press, 2006. 
Wilkinson, D. "Civilizations, cores, world economies, and oikumenes." The World System: Five Hundred Years or Five Thousand? Andre Gunder Frank and Barry Gills, eds. Routledge, London; New York, 1996: 221-246.

World Bank. The Role of Indigenous Peoples in Biodiversity Conservation: The Natural but Often Forgottern Partners. Washington: The International Bank for Reconstruction and Development / The World Bank, 2008. 